University of Nebraska - Lincoln

DigitalCommons@University of Nebraska - Lincoln

1989

\title{
Cyclostephanos lacrimis n. sp. and Cyclostephanos guatemalae n. sp.: Two New Centric Diatoms from the Fossil Record of Guatemala
}

\author{
Edward Theriot \\ Great Lakes Research Division, University of Michigan, Ann Arbor, Michigan 48109 \\ J. Platt Bradbury \\ U.S. Geological Survey, Federal Center, Denver, Colorado 80225, U.S.A.
}

Follow this and additional works at: https://digitalcommons.unl.edu/usgsstaffpub

Part of the Earth Sciences Commons

Theriot, Edward and Bradbury, J. Platt, "Cyclostephanos lacrimis n. sp. and Cyclostephanos guatemalae n. sp.: Two New Centric Diatoms from the Fossil Record of Guatemala" (1989). USGS Staff -- Published Research. 289.

https://digitalcommons.unl.edu/usgsstaffpub/289

This Article is brought to you for free and open access by the US Geological Survey at DigitalCommons@University of Nebraska - Lincoln. It has been accepted for inclusion in USGS Staff -- Published Research by an authorized administrator of DigitalCommons@University of Nebraska - Lincoln. 


\title{
Cyclostephanos lacrimis n. sp. and Cyclostephanos guatemalae n. sp.: Two New Centric Diatoms from the Fossil Record of Guatemala ${ }^{1}$
}

\author{
Edward Theriot ${ }^{2}$ and J. Platt Bradbury \\ Great Lakes Research Division, University of Michigan, Ann Arbor, Michigan 48109 and \\ U.S. Geological Survey, Federal Center, Denver, Colorado 80225, U.S.A.
}

\begin{abstract}
Two new species of Cyclostephanos are described from Pleistocene diatomites near Lago de Atitlán, Guatemala. In both species, radiating costae continue unbranched to the valve margin and the external expression of the single labiate process is an elongate pore on the mantle beneath a spine. Cyclostephanos lacrimis n. sp. is 7-75 $\mu \mathrm{m}$ in diameter and has no central area strutted processes. Each mantle strutted process is located within a marginal alveolus directly adjacent to a costa; this unique location is usually visible with light microscopy. C. guatemalae $\mathrm{n}$. sp. is smaller $(5-23 \mu \mathrm{m})$, with a single eccentrically-located strutted process and mantle strutted processes directly on every second or third costae. The best way to identify the two species on the basis of measured characters is to plot the total number of costae against diameter. Such a plot will almost completely separate the two species with slight overlap only among the smallest specimens of the two species. Costa density and valve diameter, often implicitly assumed to be independent characters, are found to have a strong curvilinear relationship in these two species and in C. fenestratus.
\end{abstract}

There have been few studies of fossil freshwater diatoms of Guatemala, although numerous diatomaceous lacustrine deposits exist (Serrano, 1960). Newhall (1987) identified diatom deposits in the region around Lago de Atitlán, a tectonically and volcanically active region. We are not aware of any previous studies of the diatoms of these deposits by taxonomic specialists. Because the deposits are associated with rocks of known age, the associated diatoms can be used to test and/or refine a proposed biochronology of freshwater centric diatoms (Krebs et al., 1987). This paper reports two new extinct species of the genus Cyclostephanos Round from some of the younger diatom deposits in the Atitlán basin.

A second objective of this paper is to evaluate different techniques for recording costa abundance in centric diatoms. Density of costae (or its equivalent, fascicle density) is traditionally used. However, costa density has never been shown to be superior to any other estimate of costa abundance in taxonomic studies. Two estimates of costa abundance, density, and total number are used

\footnotetext{
${ }^{1}$ We thank Christopher Newhall for the diatom sample from Godinez and for information on radiometric dates. Kathryn Dieterich-Rurup and Gail Emmert provided technical assistance in preparing this manuscript. This investigation was supported by NSF grant BSR 8507709 to E.T.

${ }^{2}$ Present address: Academy of Natural Sciences of Philadelphia, 19th and The Parkway, Philadelphia, Pennsylvania 19103, U.S.A.
}

Trans. Am. Microsc. Soc., 108(1): 74-86. 1989.

(C) Copyright, 1989, by the American Microscopical Society, Inc.

This article is a U.S. government work, and is not subject to copyright in the United States. 
in a comparison of three fossil species of Cyclostephanos to assess the relative taxonomic effectiveness of each.

\section{Materials AND Methods}

Material containing the two new species was collected from fossil deposits at two localities in the western highlands of Guatemala in the vicinity of Lago de Atitlán. The first collection, called Río de los Ídolos, is from a roadcut about $5 \mathrm{~km} \mathrm{NW}$ of the town of Patzun, Provincia de Chimaltenango, Guatemala $\left(14^{\circ} 42.5^{\prime} \mathrm{N}, 91^{\circ} 2.5^{\prime} \mathrm{W}\right)$. This material was collected by Bradbury (Bradbury locality number 1 VII 75-311). The second collection, called Godinez, was taken about $1 \mathrm{~km}$ E of the town of Godinez, Provincia de Solola, Guatemala $\left(14^{\circ} 42.5^{\prime} \mathrm{N}\right.$, $91^{\circ} 5.5^{\prime} \mathrm{W}$ ). This material was collected by C. G. Newhall (USGS) and is assigned Bradbury locality number 2 XI 79-1.

Although the collections are from the same general vicinity (about $5 \mathrm{~km}$ apart), their precise stratigraphic and geologic relationships are unknown. The diatomite at the Godinez locality is overlain by volcanic rocks radiometrically dated at 0.1 million years before present (Mybp) and is underlain by an ash flow tuff (Newhall, 1987). Apparently, this deposit is not a caldera deposit but represents local damming of a paleodrainage system that predated the Atitlan III caldera. Volcanic rocks beneath the diatomite are not well dated; they are believed to be less than 1 Mybp (Newhall, 1987). The age of the Río de los Idolos locality is not known, but is clearly younger than $3.3 \mathrm{Mybp}$, a radiometric date for a volcanic tuff underlying the deposit. Presumably, the Río de los Idolos deposit also represents local damming of a paleodrainage system by volcanic flows and/or associated faulting.

Cover slips with cleaned and dried material were embedded in Hyrax ${ }^{\circledR}$ for light microscopy (LM) or attached to aluminum stubs for scanning electron microscopy (SEM). LM observations were made on an Olympus Vanox ${ }^{\circledR}$ fitted with interference contrast optics. SEM observations on USGS 1 VII 75-311 were made with an ISI-DS 130 operated at $12-15 \mathrm{kV}$ accelerating voltage. SEM observations on USGS 2 XI 79-1 were made on a JEOLCO 35C operated at $20 \mathrm{kV}$.

Diameter and the total number of costae per valve were measured on each valve encountered until at least one representative of each $5-\mu \mathrm{m}$ diameter size class was recorded. For 10 valves of each species, we measured areolar density in a stria over $5 \mu \mathrm{m}$ because the valve face of both species is strongly undulate. We then doubled areolae per $5 \mu \mathrm{m}$ as an estimate of the more traditional number of areolae in $10 \mu \mathrm{m}$. We made the same measurements on isotypic material of $C$. fenestratus Theriot \& Kociolek for comparative purposes (Great Lakes Research Division ECT 708; USGS 3 IV 86-1; other slides are listed in Theriot \& Kociolek, 1986).

Terminology of diatom morphology conforms to Ross et al. (1979), with the exception of the term "lamina," a thin siliceous covering of the alveolus or marginal chamber, first used in this sense by Lowe (1975). 


\section{TAXONOMIC ACCOUNT \\ Thalassiosiraceae Lebour \\ Cyclostephanos Round \\ Cyclostephanos lacrimis n. sp.}

(Figs. 1-9)

Diagnosis. A large species of Cyclostephanos (7-75 $\mu \mathrm{m}$ diameter) distinguished from known congeners by the presence of mantle strutted processes within the alveoli, each process directly adjacent to a costa.

Type specimens. Holotype: Slide A-G.C. 30877 a at the diatom herbarium, Academy of Natural Sciences of Philadelphia (ANSP). Isotypes (LM preparations and/or unprepared material): ANSP A-G.C. 30877b, the Great Lakes Research Division diatom herbarium (GLRD; ECT 763), Theriot's personal collection ECT 763, and Bradbury 1 VII 75-311.

Type locality. Guatemala, Provincia de Chimaltenango, from a diatomite outcrop in a roadcut on Guatemalan National Highway no. 1, between the towns of Godinez and Patzun, approximately $5 \mathrm{~km}$ due $\mathrm{E}$ of the east margin of Lago de Atitlán $\left(14^{\circ} 42.5^{\prime} \mathrm{N}, 91^{\circ} 2.5^{\prime} \mathrm{W}\right.$; i.e., Bradbury locality 1 VII $\left.75-311\right)$.

Known geographic and stratigraphic distribution. The type locality is the only known geographic distribution. The species is apparently extinct.

Etymology. Specific epithet is Latin, ablative plural of "lacrima," meaning "with tears" in reference to the teardrop-shaped pore fields on the mantle.

Morphology. The following details are consistently visible by LM. Valves of C. lacrimis are strongly and concentrically undulate with radiating striae; the fascicles are uniseriate in the central area and become multiseriate toward the margin (Figs. 1-3). Striae are coarsely areolate (ca. 6-8 in $10 \mu \mathrm{m}$ ) in the central area, but are much more finely areolate (often 10 or more in $10 \mu \mathrm{m}$ ) in the multiseriate portions of the fascicles. The costae continue unbranched from the valve face onto the mantle all the way to the margin (Figs. 1-5). The teardropshaped pore field defined by costae on the mantle is clearly visible on tilted specimens.

The following exterior details are best demonstrated by SEMi, but may be visible with LM in suitably oriented specimens. The radial costae are vertically thickened externally relative to the fascicles on the valve face (Fig. 3). The fascicles are occasionally interrupted by cross-costae between the main radial costae. A costa widens laterally on the face, narrows after it passes the junction of the face and mantle, and finally spreads laterally again to join adjacent costae near the margin (Figs. 3-5). As a result, the mantle areolae fields are somewhat

FIGS. 1-6. Cyclostephanos lacrimis. Bradbury 1 VII 75-311. Fig. 1. Small specimen. Scale bar represents $5 \mu \mathrm{m}$. Fig. 2. Large specimen. Scale bar represents $10 \mu \mathrm{m}$. Fig. 3. Exterior view; arrow marks external expression of labiate process. Scale bar represents $10 \mu \mathrm{m}$. Fig. 4. Detail of mantle in Fig. 3; arrow marks external expression of labiate process. Scale bar represents $1 \mu \mathrm{m}$. Fig. 5. Detail of mantle in Fig. 3; arrow marks external expression of a strutted process. Scale bar represents $1 \mu \mathrm{m}$. Fig. 6. Internal view; arrow marks broken margin detailed in Fig. 8. 

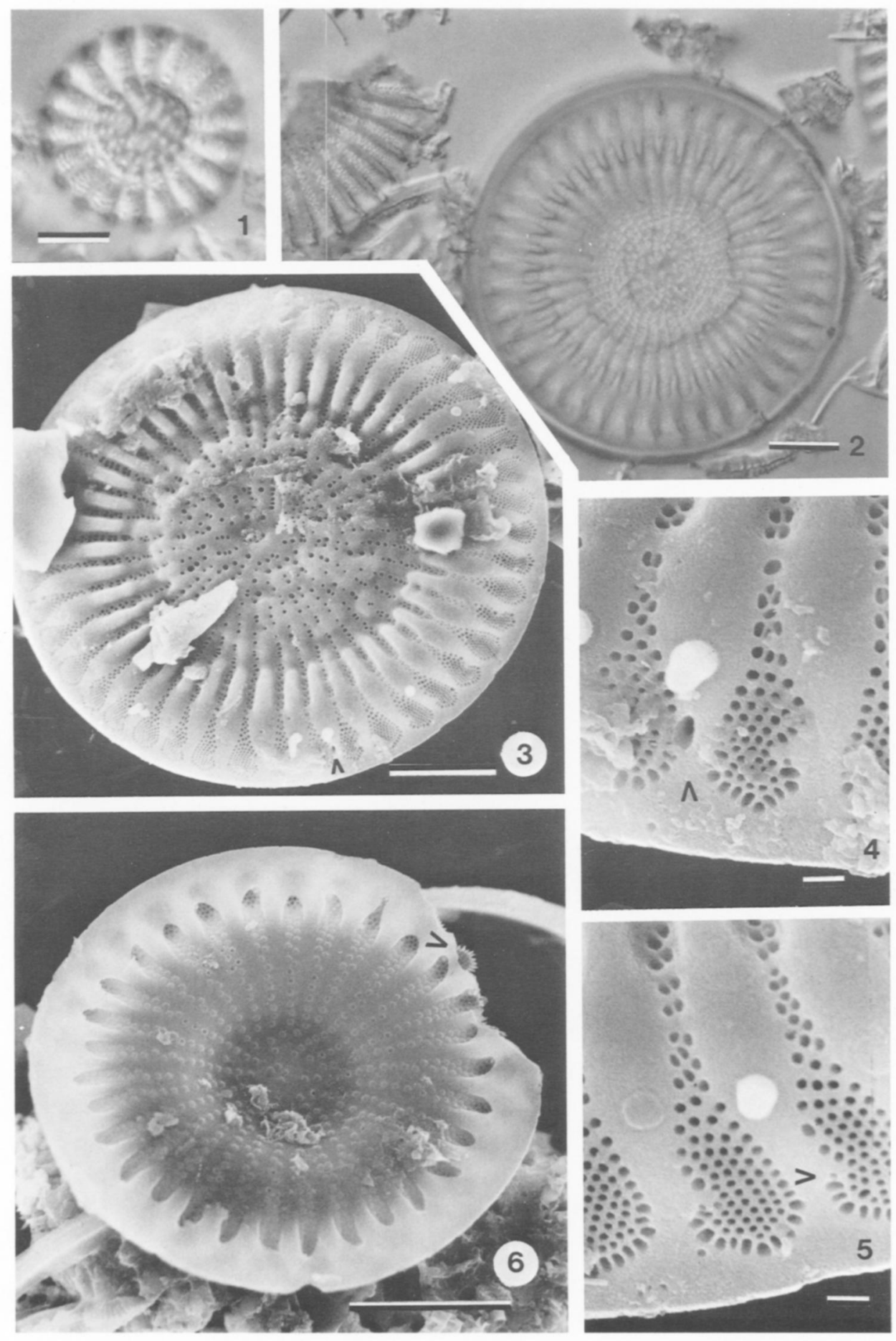

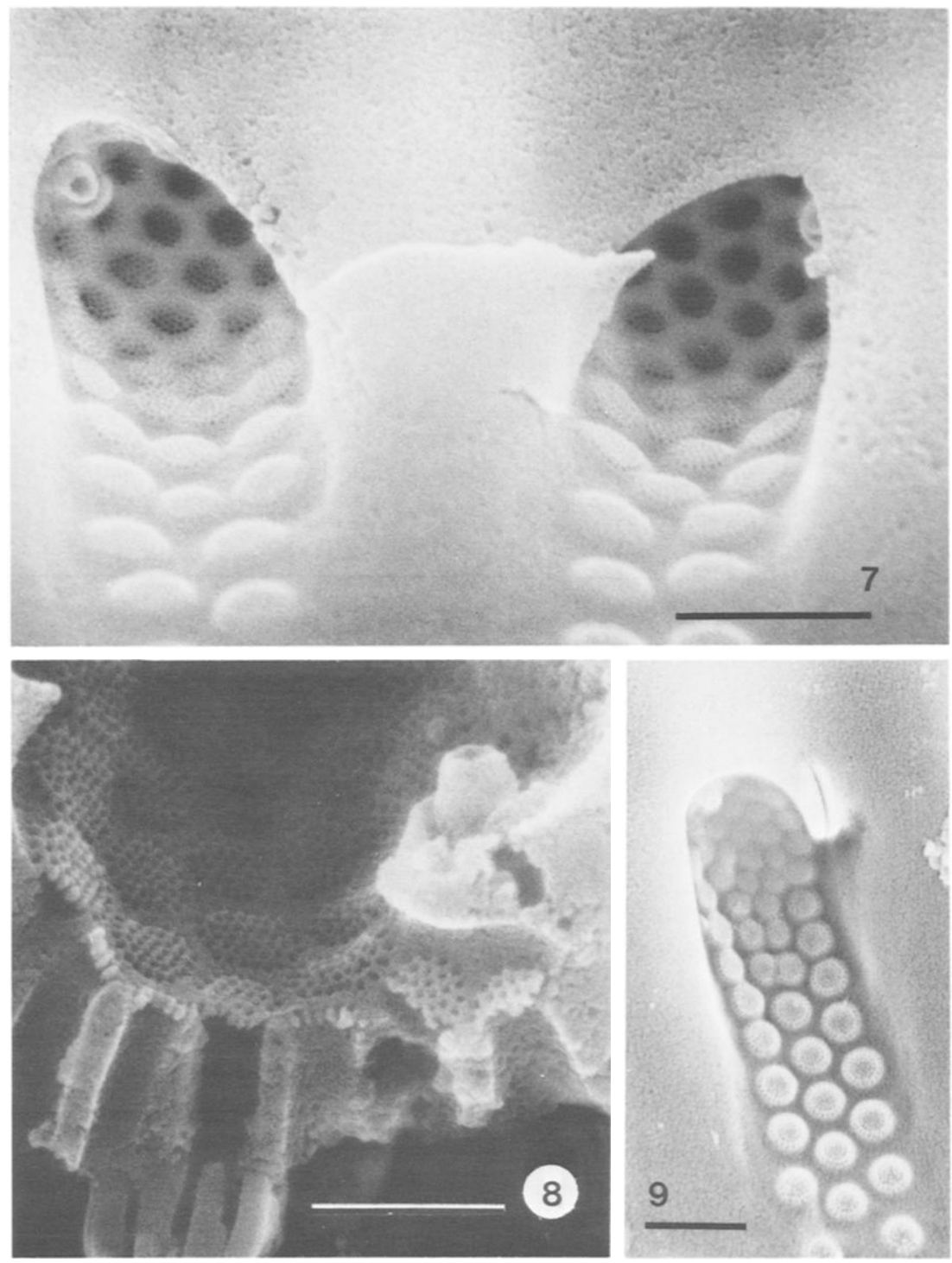

FIGS. 7-9. Cyclostephanos lacrimis. Bradbury 1 VII 75-311. Fig. 7. Detail of alveoli. Scale bar represent $1 \mu \mathrm{m}$. Fig. 8. Detail of cribra of alveolus from valve in Fig. 6 . Scale bar represents 0.5 $\mu \mathrm{m}$. Fig. 9. Internal view of alveolus with a labiate and strutted process. Scale bar represents $1 \mu \mathrm{m}$.

set off from the fascicles of the face and are teardrop-shaped (Figs. 4, 5). Occasional pores occur on costae of the valve face; we are uncertain of their nature. As is often the case in Cyclostephanos and the morphologically similar genus Stephanodiscus, the areolar organization on the internal surface is more regular than that of the external surface; views of the internal surface do not provide a clear indication of the nature of odd pores on the exterior surface. 
Details of the valve interior also are best demonstrated by SEM. The cribra of the valve face areolae are strongly domed over most of the valve face, become flat or nearly so near the junction of the face and mantle, and continue so to the margin (Figs. 6-9). The region of flattened cribra also is marked by a slight internal thickening of the costae relative to the fascicle (Fig. 7). The thickened costae form a shallow trough (alveolus) extending to the margin. The costae widen internally at their distal ends and join with laminae to cover the distal portion of the alveolus (Figs. 6-9); the interior margin of the laminae can be seen with LM in large specimens.

Processes of various types occur only in the mantle region. A spine or spine remnant is found on most costae near the junction of the face and mantle (Figs. 3-5). Strutted processes are located on the mantle on the side of almost every costa (Figs. 5, 7-9). The resultant deformation of the mantle costa is visible even with LM on tilted specimens. Each strutted process has two satellite pores internally and is marked externally by a small pore in the middle of a small hyaline field on the side of the costa. Apparently, there is no regular orientation (either on one side of the costa or the other) to strutted process placement. No alveolus was observed to have two strutted processes. The costa occupied by the labiate process does not have a strutted process. The internal opening of the labiate process is a radially oriented, raised slit on the lamina covering the alveolus; its external opening is a radially oriented, elongate pore beneath a spine (Figs. 4, 9). The labiate process is often visible with LM as a large punctum on a mantle costa.

Presumed depositional environment as indicated by associated siliceous microfossils. Examination of surface sediments indicates that Cyclostephanos lacrimis does not live in Lago de Atitlán today (Bradbury, unpublished observations). The type sample was a pure diatomite, indicative of a silica-rich environment. The large diameter and heavy silicification of the species is comparable to that of large planktonic species of Stephanodiscus in the oligotrophic upper Laurentian Great Lakes. Cyclostephanos lacrimis was by far the dominant diatom, estimated at well over $90 \%$ of the assemblage. Attached or benthic diatoms such as Fragilaria pinnata var. intercedens (Grunow) Hustedt, Cocconeis placentula var. lineata (Ehrenb.) Van Heurck, Cymbella cistula (Ehrenb.) Kirchner, and Achnanthes lanceolata var. dubia Grunow each made up less than $1 \%$ of the total assemblage. This benthic assemblage is similar to that of nearshore assemblages in Lago de Atitlán today. The growth environment of C. lacrimis was apparently similar to the present Lago de Atitlán, a highly transparent, low-productivity lake with a relatively small littoral environment.

\section{Cyclostephanos guatemalae n. sp.}

(Figs. 10-19)

Diagnosis. A medium sized species of Cyclostephanos (5-23 $\mu \mathrm{m}$ diameter) distinguished from known congeners by the presence of mantle strutted processes in small depressions in the costae.

Type specimens. Holotype: Slide A-G.C. 30878 a at the diatom herbarium, Academy of Natural Sciences of Philadelphia (ANSP). Isotypes: LM prepara- 


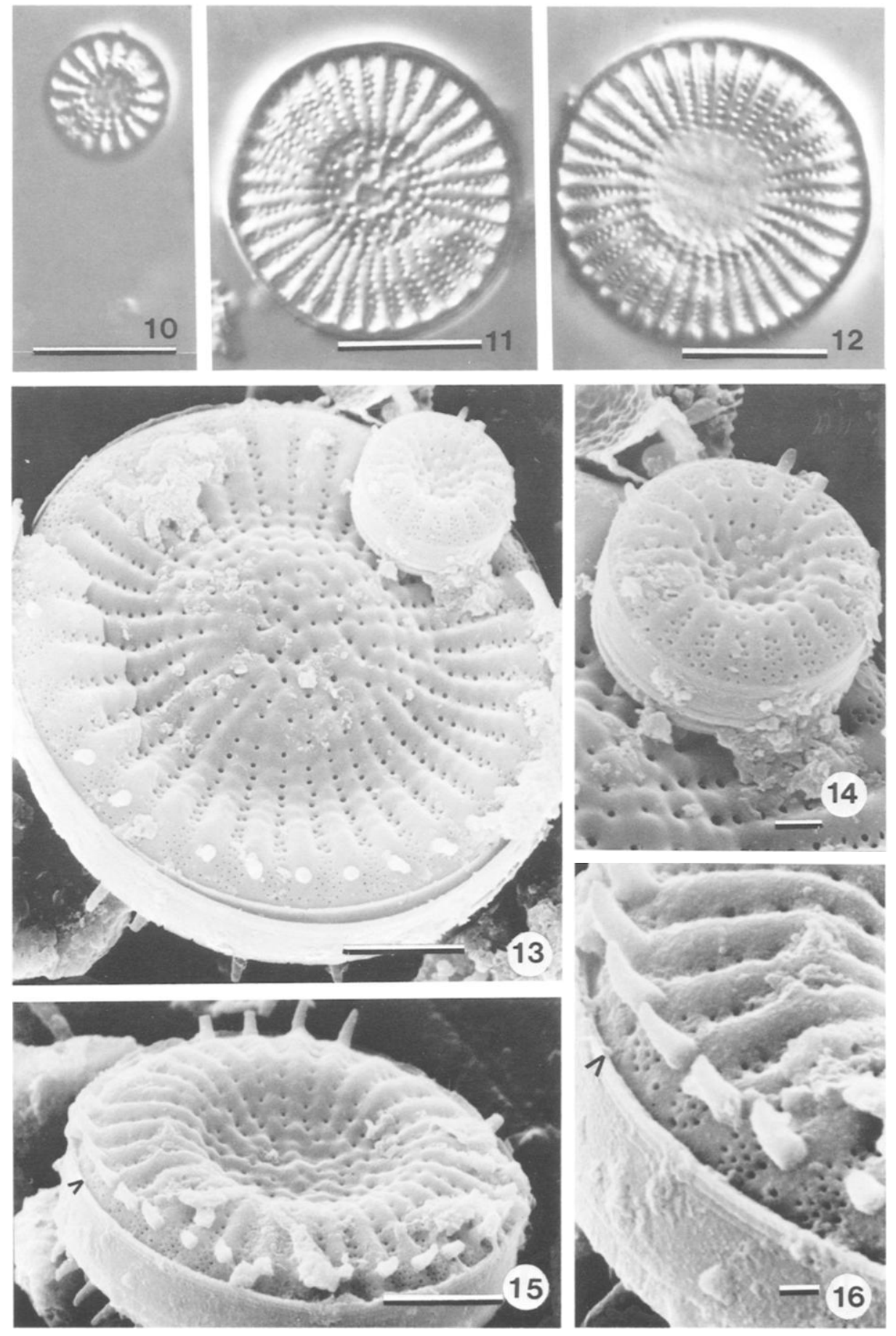



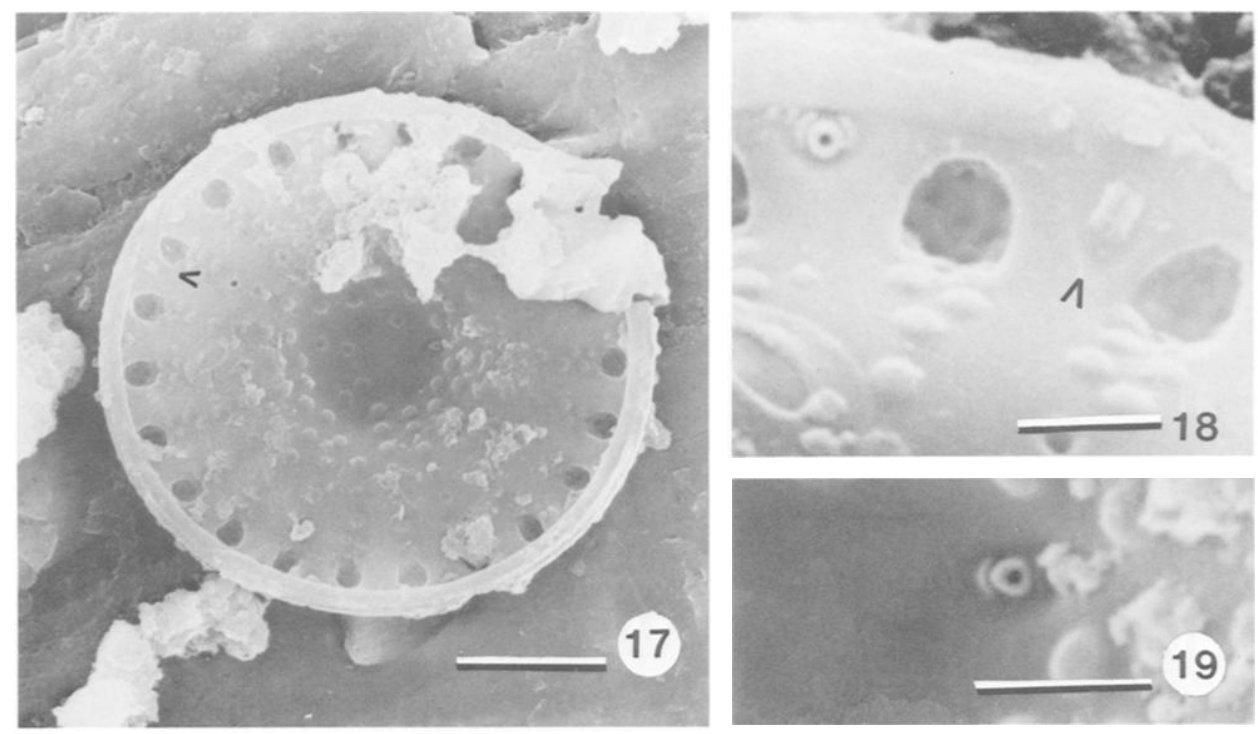

FIGS. 17-19. Cyclostephanos guatemalae. Bradbury 2 XI 79-1. Fig. 17. Internal view; arrow marks labiate process. Scale bar represents $5 \mu \mathrm{m}$. Figs. 18, 19. Detail of alveoli and central area strutted process of valve of Fig. 17; arrow marks labiate process. Scale bars each represent $1 \mu \mathrm{m}$.

tions and/or unprepared material: ANSP A-G.C. 30878b, California Academy of Sciences diatom herbarium, Great Lakes Research Division diatom herbarium (GLRD), Theriot's personal collection ECT 762, and Bradbury 2 XI 79-1.

Type locality. Guatemala, Provincia de Solola, about $1 \mathrm{~km} \mathrm{E}$ of town of Godinez $\left(14^{\circ} 42.5^{\prime} \mathrm{N}, 91^{\circ} 5.5^{\prime} \mathrm{W}\right.$, i.e., Bradbury locality 2 XI 79-1).

Known geographic and stratigraphic distribution: The type locality is the only known locality. The species seems to be extinct.

Etymology. Specific epithet is Latinization of Guatemala, genitive singular case meaning "of Guatemala."

Morphology. Using LM, valves appear concentrically undulate with radially arranged costae between fascicles of areolate striae (Figs. 10-12). Fascicles are uniseriate in the central area and multiseriate away from the center; visible with LM and SEM (Figs. 10-16). There are about 10-16 areolae in $10 \mu \mathrm{m}$ of

FIGS. 10-16. Cyclostephanos guatemalae. Bradbury 2 XI 79-1. Figs. 10-12. Three specimens of different size and different levels of focus. Scale bars each represent $10 \mu \mathrm{m}$. Fig. 13. External view of large specimen with convex center. Scale bar represents $5 \mu \mathrm{m}$. Fig. 14. Small specimen. Scale bar represents $1 \mu \mathrm{m}$. Fig. 15. Large specimen with concave central area; arrow marks the external opening of the labiate process. Scale bar represents $5 \mu \mathrm{m}$. Fig. 16. Detail of mantle of specimen of Fig. 15; arrow marks opening of labiate process beneath a spine. Scale bar represents $1 \mu \mathrm{m}$. 
a stria. Cribra are domed on valve face areolae and appear to be flat on marginal areolae, but this is less clearly resolved (Figs. 17-19). Externally raised costae separate the fascicles of striae and extend to the valve margin. Internally, these costae are observed to be thickened internally near the margin and form small alveoli.

There are three types of valve processes. There is a spine on almost every costa (Figs. 13-16). There is a strutted process in the central area and one in a depression on every 2 nd-4th costae on the mantle (Figs. 17-19). Each strutted process has two satellite pores internally and occurs as a small pore on the costa under a spine (Figs. 16, 18). The eccentrically located central area strutted process also occurs in a depression and has two satellite pores (Fig. 19), but it has no obvious external expression. The single labiate process (LP) occurs on the mantle roughly opposite the central area strutted process (Fig. 17). It has a radially oriented slit internally and occurs between two strutted processes rather than disturbing the rotational symmetry of the latter (Figs. 17, 18). The LP external expression is an elongate pore on a mantle costa beneath a spine.

Presumed depositional environment as indicated by associated siliceous microfossils. Study of surface sediments indicates that C. guatemalae is not living in modern Lago de Atitlán. The sample studied was from a pure diatomite. The size and degree of silicification of C. guatemalae is similar to that of planktonic species of Stephanodiscus in oligotrophic-mesotrophic environments of the Laurentian Great Lakes. The preserved assemblage indicates a somewhat shallower and more productive environment than that of C. lacrimis or of modern Lago de Atitlán. It is dominated by C. guatemalae, Melosira granulata (Ehrenb.) Ralfs, and Synedra acus Kützing in approximately equal proportions. Nitzschia gandersheimiensis Krasske is also relatively abundant, as is the attached diatom Cocconeis placentula var. lineata.

Remarks. The stratigraphic and paleolimnologic significance of C. lacrimis and $C$. guatemalae is unknown. The species appear to be extinct and might be useful for time correlation of sediments within the Atitlán basin or perhaps a wider area of Central America. Studies of other diatomaceous deposits in the region may help understand the enigmatic stratigraphic and geographic relationships of these two species of Cyclostephanos.

\section{Results AND Discussion}

Theriot et al. (1987) reviewed all the known described species of Cyclostephanos. The only two of these which may be easily confused with the Guatemalan species are the genus lectotype, C. novaezeelandiae (Cleve) Round, and C. fenestratus Theriot \& Kociolek. The former is the only species of Cyclostephanos known to us which is as large as C. lacrimis. However, C. novaezeelandiae has branching costae (visible in LM), mantle strutted processes directly on the mantle costae, and a less strongly undulate central area. There are several distinctions between the two Guatemalan species and C. fenestratus based on SEM (Table I).

Cyclostephanos lacrimis also may be distinguished with LM. All qualitative data on C. fenestratus are from Theriot \& Kociolek (1986). The visibly obvious 
TABLE I

Characteristics of Cyclostephanos lacrimis n. sp., C. guatemalae n. sp., and C. fenestratus Theriot \& Kociolek based on SEM

\begin{tabular}{|c|c|c|c|}
\hline & C. lacrimis & C. guatemalae & C. fenestratus \\
\hline CSP & No & Yes & No \\
\hline No. satellite pores on MSP & 2 & 2 & 3 \\
\hline MSP location & In alveolus on side of costa & In depression on costa & On costa \\
\hline Lamina & Yes & Yes & No \\
\hline LP in depression & No & Yes & No \\
\hline Costae/MSP & $1 / 1$ & $1 / 2-1 / 4$ & $1 / 1-1 / 4$ \\
\hline
\end{tabular}

Abbreviations: CSP, central area strutted process; LP, labiate process; MSP, mantle strutted process.

marginal laminae of large specimens of C. lacrimis (greater than $30 \mu \mathrm{m}$ ) distinguish them from $C$. guatemalae and C. fenestratus. The mantle strutted processes are usually visible on the sides of mantle costae of C. lacrimis as small lateral thickenings. In the other two species, the mantle strutted processes appear as small puncta directly on the mantle costae in those rare instances when they are visible at all. Finally, the mantle costae of $C$. lacrimis thin noticeably as they approach the margin, forming the characteristic teardrop-shaped alveolus by way of contrast to the other species.

Diatoms that are as distinct as C. guatemalae and C. fenestratus using SEM are often easily distinguished with LM, but not in this case. The costae of $C$. fenestratus, especially those without strutted processes, rarely reach the margin, whereas costae of $C$. guatemalae always reach the margin. When the costae of $C$. fenestratus reach the margin, they do not flare laterally as do those of C. guatemalae. This difference is more apparent in larger specimens. The central area of $C$. fenestratus is abruptly set off from the rest of the face by high curvature of the wall, contrasting to the more gentle slope of C. guatemalae. Quantitative LM data do not separate the two (e.g., Fig. 20).

Costae data can be used to separate, however, C. lacrimis from the other two species, especially among larger sized specimens (Fig. 20). Only one morphometric study has been made previously of Cyclostephanos (Hickel \& Håkansson, 1987). Thus, we discuss our results in detail and comment on the classical use, possibly misuse, of costa density. In most centric diatoms, the abundance of costae (or equally, the abundance of fascicles) is expressed as the number in $10 \mu \mathrm{m}$ rather than the total number. There is no consensus as to whether the number of costae should be counted along $10 \mu \mathrm{m}$ of a tangent to the valve margin or $10 \mu \mathrm{m}$ of the valve circumference. There is at least one recognized difficulty with measuring tangential density. Collins \& Groetsch (1981) realized that degree of error in measuring rotational elements along a tangent or cord will likely increase among small centric diatoms; they developed a table of values for diatoms below $15 \mu \mathrm{m}$ based on a series of equations.

Our diatoms span diameters from well below to well above $15 \mu \mathrm{m}$. To avoid estimating tangential fascicle density by two methods (the Collins \& Groetsch, 1981, table and direct measurement) or applying a more complicated than necessary equation to the data, we took the more direct approach of dividing 

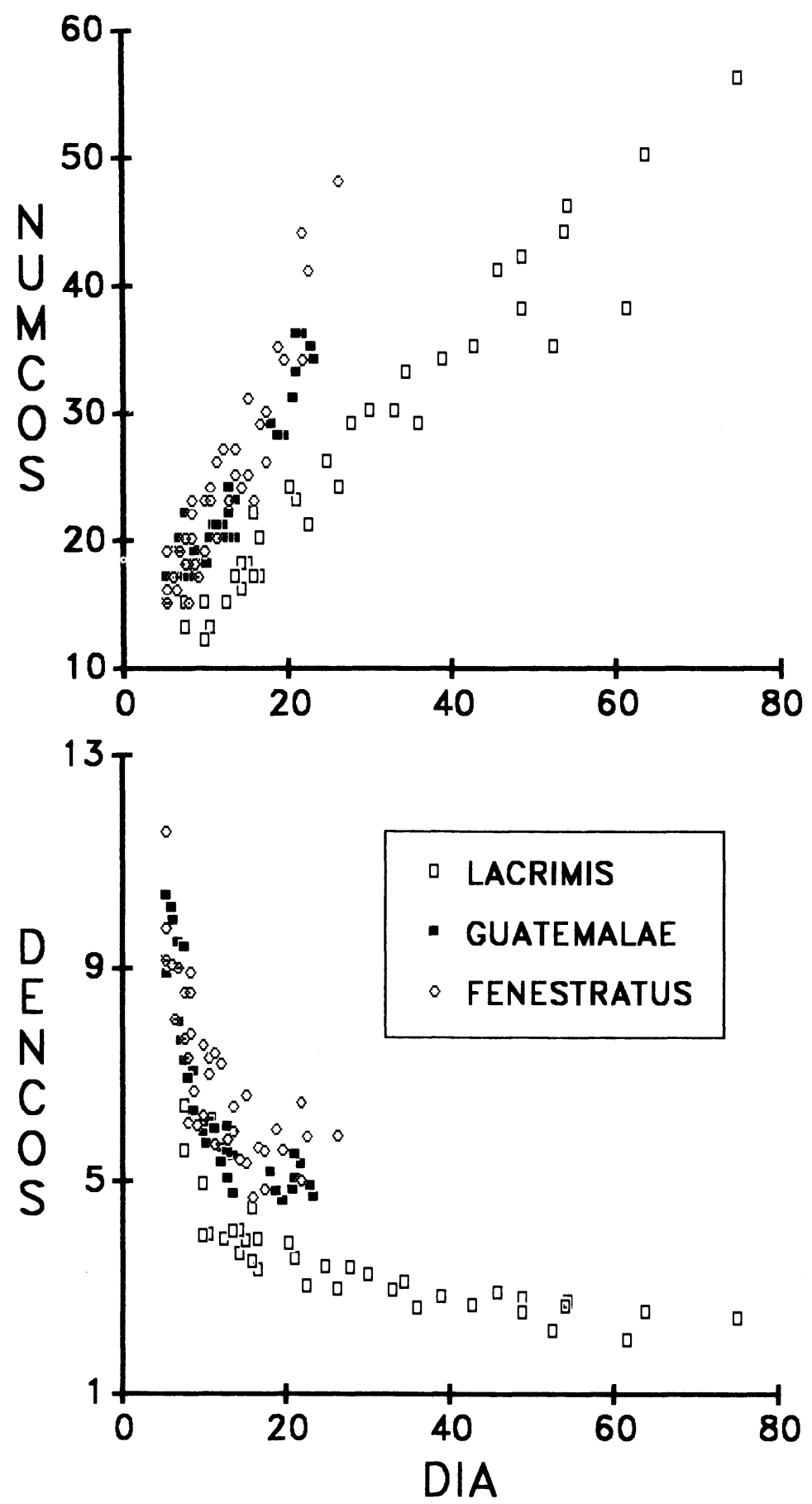

FIG. 20. Scatter plot of total number of costae (NUMCOS) and density of costae in $10 \mu \mathrm{m}$ of circumference (DENCOS) against diameter in $\mu \mathrm{m}$ for Cyclostephanos lacrimis, C. guatemalae and $C$. fenestratus. 
costa number by valve circumference (=number per $10 \mu \mathrm{m}$ of circumference). Costa density is correlated with diameter, but in a curvilinear pattern (Fig. 20). A plot of costa density against diameter reveals that a non-linear discriminant function would be required to achieve the same degree of species separation as would a linear discriminant function on a plot of total costae against diameter (Fig. 20). Two specimens of different species of the same diameter might be similar in costa density, but two specimens of the same species, differing only by a few micrometers, can be very different in costa density and appearance because of the curvilinear relationship.

A curvilinear relationship between costa density and diameter may be widespread among the freshwater genera of the Thalassiosiraceae, if not among all centric diatoms. Genkal $(1979,1984)$ reports such a relationship in the similar genera Stephanodiscus Ehrenb. and Cyclotella Kützing. Hickel \& Håkansson (1987) noted an association between diameter and costa density in Cyclostephanos dubius (Fricke) Round, but did not mention whether or not the relationship was statistically significant and/or linear.

Diatomists are correctly concerned about the underlying genetic basis of character variation. A character that shows some degree of size and/or environmentally correlated variation is usually considered "bad" in some sense by diatomists. Nevertheless, biometric studies can provide estimates of the genetic contribution to character variation in diatoms in laboratory experiments (Wood et al., 1987). A genetic component to variation in diatom characters with strong size or environmental dependence can be inferred from natural experiments as well (Theriot \& Stoermer, 1986; Theriot, 1987). However, another fundamental problem has received little study; i.e., identification of those counts or measurements producing the least redundant and statistically most tractable set of data for biometric analysis.

We are unaware of any argument as to why costa or fascicle density has been classically preferred as a character over total costa number in centric diatoms. We suspect the preference is because of an unpublished, but widely held, perception that total number is always dependent on diameter, whereas costa density is somehow more "stable" or "conservative." In the analysis of these fossil species of Cyclostephanos, total costa number is a better measure of costa abundance than is costa density because the former can be correlated with diameter in a simple linear way, but costa density and valve diameter covary in a curvilinear pattern.

\section{Literature Cited}

Collins, G. B. \& Groetsch, C. W. 1981. An elementary mathematical problem arising in diatom taxonomy. Int. J. Math. Educ. Sci. Technol., 12: 121-124.

GENkAL, S. I. 1979. Zakonomernosti izmenchivosti osnovnik strukturnik elementov pantsirya u diatomovik vodoroslei roda Cyclotella Kütz. Bio. Vnutr. Vod Inf. Byull., 59: 14-16.

1984. O morfologicheskoi izmenchivosti osnovnik elementov stvorki u vidov roda Stephanodiscus (Bacillariophyta). Bot. Zh., 69: 403-408.

HiCkel, B. \& HÅkansson, H. 1987. Dimorphism in Cyclostephanos dubius (Bacillariophyta) and the morphology of initial valves. Diatom Res., 2: 35-46.

$\rightarrow$ Krebs, W. N., Bradbury, J. P. \& Theriot, E. 1987. Neogene and Quaternary lacustrine diatom biochronology, western USA. Palaios, 2: 505-513. 
Lowe, R. L. 1975. Comparative ultrastructure of the valves of some Cyclotella species (Bacillariophyceae). J. Phycol., 11: 415-424.

Newhall, C. G. 1987. Geology of the Lake Atitlán region, western Guatemala. J. Vulcan. Geotherm. Res., 33 (In press)

Ross, R., Cox, E. J., Karayeva, N. I., Mann, D. G., Paddock, T. B. B., Simonsen, R. \& Sims, P. A. 1979. An amended terminology for the siliceous components of the diatom cell. Nova Hedwigia, Beih., 64: 513-533.

Serrano, M. 1960. Descrubimiento de Nuevos Yacimientos de Diatomita en el Occidente de la Republica de Guatemala. Universidad de San Carlos de Guatemala, San Carlos. 59 pp.

Theriot, E. 1987. Principal component analysis and taxonomic interpretation of environmentally related variation in silicification in Stephanodiscus (Bacillariophyceae). Br. Phycol. J., 22: 359-373.

Theriot, E. \& Kociolek, J. P. 1986. Two new Pliocene species of Cyclostephanos (Bacillariophyceae) with comments on the classification of the freshwater Thalassiosiraceae. J. Phycol., 22: 121-128.

Theriot, E. \& Stoermer, E. F. 1986. Morphological and ecological evidence for two varieties of the diatom Stephanodiscus niagarae. In Ricard, M., ed., Proc. 8th Internat. Diat. Symp., Koeltz, Koenigstein, pp. 385-394.

Theriot, E., Stoermer, E. F. \& HÅkansson, H. 1987. Taxonomic interpretation of the rimoportula of freshwater genera in the centric diatom family Thalassiosiraceae. Diatom Res., 2: 251-265.

Wood, A. M., Lande, R. \& Fryxell, G. A. 1987. Quantitative genetic analysis of morphological variation in an Antarctic diatom grown at two light intensities. J. Phycol., 23: 42-54. 